\title{
タイムプレッシャーが弁別難易度の異なる弁別反応時の P300とLRPに及ぼす影響1
}

\author{
広島大学大学院教育学研究科 \\ 白石 舞衣子・宮谷 真人
}

\section{The effects of time pressure and discriminability on P300 and lateralized readiness potential}

\author{
Maiko Shiraishi and Makoto MiYatani \\ Department of psychology, Graduate School of \\ Education, Hiroshima University, 1-1-1, Kagamiyama \\ Higashi-Hiroshima 739-8524, Japan
}

The effects of time pressure (TP) on stimulus evaluation and reaction preparation processes were investigated using P300 and the lateralized readiness potential (LRP). Event-related potentials (ERPs) of participants performing visual and auditory discrimination tasks were recorded. TP was manipulated by using moderate or severe response time limits. TP effects on the P300 and LRP latency were compared between two levels of discriminability, which was manipulated by stimulus intensity. Results indicated that P300 latency was reduced by severe TP only when discrimination was difficult. LRP latency was affected by TP regardless of stimulus intensity. These results suggest that the durations of both stimulus evaluation process and reaction preparation process were reduced by TP. (Japanese Journal of Physiological Psychology and Psychophysiology, 23(3) : 227-236, 2005.)

Key words: time pressure, P300, lateralized readiness potential

2005.4.11 受稿, 2005.12.27 受理

1) 本研究は科学研究費補助金 (B14310042)により実施した. 
【要 約】本研究ではタイムプレッシャー(以下 TP) が刺激評価過程や反応準備過程に及ぼす影響について, P300 と LRPを指標として検討した. 視覚および聴覚刺激を用いた弁別課題を遂行中の参加者からERPを記 録した，TPは反応に許される制限時間の長さで操作し，P300 と LRPの潜時に及ぼす TP の効果を弁別の難易 度が異なる2つの条件間で比較した。弁別の難易度は刺激強度によって操作した。P300の潜時は并別が困難 な条件でのみ，TPの影響を受けて短縮した，LRPの潜時は刺激強度にかかわらずTPの影響を受けた。これ らの結果は, 刺激評価過程と反応準備過程の両方が, TPによって短縮されることを示唆する.

人間は，時間的制約を受けながら何か作業をした り，意思決定したりしなければならない時にタイム プレッシャー ( 以下 $\mathrm{TP}$ )を感じる、本研究では，意 思決定などの活動を行う際の時間的制約の認識とそ れに伴う焦り，急き，慌てなどを総称して TP と呼ぶ。 TPが意思決定などの認知過程に影響を及ぼすことが 報告されている，例えば，Orasanu \& Connolly (1993) はTPにより意思決定者は強いストレスを感じ，疲 弊し, 注意を欠き, より単純な推論方略を用いて思 考するようになることを指摘した。 またSharma \& McKenna (2001) は, 感情ストループ効果, すなわち 単語の色をキー押しで選択する課題の反応時間が中 性語に比べて感情語に対して遅延する効果が, TP によって増大することを報告している，災害時での 行動選択や遅刻しそうな時の車の運転のように, 判 断にスピードが求められるような状況では, 通常で は起こりにくいエラーが生じることがある。このよ うな状況下では，エラーが致命的になる可能性が高 いとされる．TP下の認知活動は，多くの専門的職 業においては慢性的な状態であると考えられており (Edland \& Svenson, 1993), TPが認知活動に及ぼす影 響の詳細について検討する必要があると考えられる.

人間の意思決定を支える情報処理過程には，刺激 入力から運動反応出力までの情報処理の流れがある とされ, 認知 (刺激評価) 系と反応 (運動出力) 系に 大別される. TP はストレッサーとしてこの情報処 理過程に影響を及ぼすと考えられている(Wickens \& Hollands, 1999)が, どのような状況で, ぞの過程に, ぞのように影響を与えるのかについては十分に検討 されていない. 認知系と反応系への影響を区別して 検討することによって, TPの影響の機序を理解でき, TP のようなストレッサーによるヒューマン・エラー の原因となる情報処理過程を解明できると考えられ る.

認知系の過程と反応系の過程への TP の影響を区
別して評価するための有効な手段として, 事象関連 電位 (event-related potentials: ERP)が挙げられる. P300 は認知系の刺激評価過程を反映し, 反応出力 と独立していると考えられている (Kutas, McCarthy, \& Donchin, 1977)。また，偏側性準備電位 (lateralized readiness potential: LRP) は, 反応系の過程である運 動の活性化開始 (反応準備) を反映していると考え られている(Coles, 1989).

Falkenstein, Hohnsbein, \& Hoormann (1994b) は, 簡 単な弁別反応課題での刺激評価時間に及ぼす TPの 効果について, P300を指標として検討している. 彼らは単純反応課題でみられる $\mathrm{P} 300$ や選択反応課 題でみられる二峰性のP 300 の 1 番目のコンポーネ ントをP-SR(刺激評価を反映) とし, 選択反応課題 でのみみられる二峰性のP 300 の 2 番目のコンポー ネントをP-CR( 刺激一反応のマッピングを反映) と 区別して TPの影響を調べた。 P-CR は直接観察する ことができない場合があるため, 選択反応課題の波 形から単純反応課題の波形を引いた差波形によって 推測される. その結果, TPによって P-SR 潜時は変 化しないが, P-CR 潜時は短縮したため, 刺激と反 応をマッピングする過程は TPによって加速すると 考えられている. また, Van der Lubbe, Jaśkowski, Wauschkuhn, \& Verleger(2001)は, 刺激一反応マッピ ングが複雑なサイモン課題での TP の効果について, 反応準備過程を反映するLRPを指標として検討し ている. 刺激に同期した LRP は運動の活性化開始 前の過程を反映し, 反応に同期したLRPは運動の 活性化開始後の過程を反映するとされている (Osman \& Moore, 1993). その結果, 反応に同期した LRP 潜時が短縮し，TPによって反応準備から反応 実行までにかかる時間が短縮すると報告している.

これらの研究から, 現在のところ, TPが反応準 備過程に影響を及ぼすことが明らかとなっている。 一方，TPが刺激評価過程に影響するという報告は 
ない。しかし，本当に TP は刺激評価過程に影響を 及ぼさないのだろうか. Maule \& Edland(1997)によ ると, TP 下の意思決定では, 情報処理の速度やテ ンポを上げる，より選択的に処理する，優先させる 情報処理を変える, 意思決定ルールを変更する, と いった適応方略が変化すると考えられており, 状況 によってはTPが刺激評価過程にも影響しうると推 測される. Falkenstein et al. (1994b) は刺激評価の易 しい刺激を用いており，刺激評価に時間を費やさな くてもよい課題であったために，TPの影響が小さく， 刺激評価過程には TPの影響がみられないという結 果が生じた可能性がある. TPが刺激評価過程に全 く影響を及ぼさないのか, 状況によっては影響する のかを確認するために，より刺激評価が困難な事態 での検討が必要であると考えられる.

そこで本研究では, 刺激強度を低下させることに よって知覚的符号化を難しくした条件を含む弁別課 題を用いて，TPが反応選択の下位過程である刺激 評価過程にどのように影響を及ぼすのかについて P300を指標として検討した。 また，すでに報告さ れている反応準備過程に及ぼす TP の効果が, 刺激 評価の難易度によって影響を受けるかどうかについ て調べた.

\section{方 法}

参加者 視力 (矯正視力を含む), 聴力の正常な 右手利き成人 12 名 (男性 5 名, 21 - 33 歳) が実験 に参加した，その内，全条件で 20 回以上の加算回 数が得られた 9 名のデー夕を分析対象とした。

刺激 モダリティと評価の難易度, 文字の種類を 組み合わせた 8 種類の刺激を用いた。視覚刺激 $(0.2$ $\times 0.5^{\circ}$ の “F”と“J”，観察距離 $\left.75 \mathrm{~cm}\right)$ は $26.3 \mathrm{~cd} / \mathrm{m}$ (易刺激) および $4.5 \mathrm{~cd} / \mathrm{m}^{2}$ (難刺激) の灰色の文字で あり, 背景 $2.2 \mathrm{~cd} / \mathrm{m}$ の液晶モニターに呈示した。聴 覚刺激として，75 dB SPL( 易刺激) および $55 \mathrm{~dB} \mathrm{SPL}$ ( 難 刺激)のデジタル音声 (“F”と“J”) を参加者前方のス ピーカーから呈示した。これらの刺激の強さは, Verleger, Neukäter, Kömpf, \& Vieregge (1991) と Sugg \& Polich(1995)に近似した值に設定した８種類の 刺激をランダムな順序で 200 試行 $(25 \times 8$ 刺激 $)$ 連 続して呈示した. 刺激の呈示時間は視覚刺激が $300 \mathrm{ms,}$ 聴覚刺激が 290 ms であった。刺激間間隔 (onset - onset 間隔)は, $1050-2550 \mathrm{~ms}$ の範囲でランダムと した.

課題 単純反応課題と, $\mathrm{TP}$ の異なる 2 つの選択反 応課題を実施した。参加者は単純反応課題では 8 種 類の刺激すべてに対し，右のキ一を押して反応した. 選択反応課題では視覚および聴覚刺激の “F”に対し て左のキー, “泫”対して右のキ一を押して反応した. 制限時間を単純反応課題と高 $\mathrm{TP}$ 選択反応課題では $400 \mathrm{~ms}$, 中 TP 選択反応課題では $550 \mathrm{~ms}$ とし, その 時間内に反応するよう参加者に教示した。制限時間 内に反応できなかった時にはフィードバック音で知 らせた。

手続き 各課題を 4 ブロックずつ(1ブロック 200 試行 ) 実施した。課題の実施順序は参加者間で力ウ ンターバランスした。 同一課題の 4 ブロックは連続 して実施した。 各課題終了後に主観的 TP 感を測定 するために日本語版 NASA - TLX ( 芳賀 - 水上, 1996)を実施した.

脳波の記録と分析 銀・塩化銀電極を用い, Fz, Cz, C3，C4，Pz，Ozから脳波を，左眼窩上下から垂直 眼電図を導出した。左右耳架にも電極を置き, 電位 を記録した。電極間抵抗は, $5 \mathrm{k} \Omega$ 以下であった。 脳波と眼電図はデジタル脳波計 $\mathrm{EEG}-1100$ ( 日本光 電) を用いて増幅した。この脳波計では, 記録時の 基準電極は $\mathrm{C} 3$ と $\mathrm{C} 4$ の平均電位, 带域通過周波数は $0.016-300 \mathrm{~Hz}$ となる。 サンプリング周波数は $1000 \mathrm{~Hz}$ であった。

オフライン処理で両耳架の平均を基準とする電位 を計算し, さらに $0.08-30 \mathrm{~Hz}$ のデジタルフィルター によって処理したデータを分析した。 分析区間は刺 激呈示前 $100 \mathrm{~ms}$ から呈示後 $800 \mathrm{~ms}$ の間とし, 刺激 呈示前区間をべースラインとして各試行における振 幅を算出した。 䛊反応, 制限時間よりも反応時間が 長い試行, いずれかのチャンネルで $100 \mu \mathrm{V}$ 以上の 振幅を記録した試行を除き, 刺激 ( 視覚・易, 視覚・ 難, 聴覚・易, 聴覚・難) 之課題 (単純反応, 高 $\mathrm{TP}$, 中 TP) を組み合わせた 12 条件別に加算平均した. 各条件の加算回数が 20 回に満たなかった参加者の デー夕は関連する分析から除外し，9名のデー夕を 分析対象とした.さらに，各条件において選択反応 課題から単純反応課題の波形を引いた差波形を算出 した。また，C3 およびC4の波形から，反応に同期 
したLRPを算出した。分析区間は反応前 $300 \mathrm{~ms}$ ら反応後 $200 \mathrm{~ms}$ とし, ベースラインは刺激呈示前 区間 $100 \mathrm{~ms}$ とした.

\section{結 果}

主観的側面 課題における TP 操作の妥当性を確 認するために, 高 $\mathrm{TP}$ 条件および中 $\mathrm{TP}$ 条件の NASA - TLXの下位項目 (知的- 知覚的要求, 身体的要求, $\mathrm{TP}$, 作業成績, 努力, フラストレーション)の得点 $(0-100$ 点)について, 下位項目ごとに $t$ 検定を行 つた，その結果， TP の項目において，中 TP 条件よ りも高 TP 条件で得点が有意に高かった $(t(8)=3.09$, $p<.05$ ).

行動測度 各条件の平均反応時間および制限時間 を超えた試行の割合をTable 1 に示す。単純反応課 題における反応時間について, モダリティ( 聴覚, 視覚) $\times$ 刺激強度 (易刺激, 難刺激) の 2 要因分散分 析を行つたところ，モダリティの主効果 $(F(1,8)=$ 123.63, $p<.0001)$, 刺激強度の主効果 $(F(1,8)=$ $410.3, p<.0001)$ ，モダリティメ刺激強度の交互作用 $(F(1,8)=33.06, p<.001)$ が有意であった，反応時間 は聴覚刺激よりも視覚刺激に対して，易刺激よりも 難刺激に対して長かった。また，難刺激に対する反 応時間の遅延は視覚条件よりも聴覚条件で大きかっ た.

選択反応課題における反応時間について, TP( 高 TP,
中 TP) $\times$ モダリティ $\times$ 刺激強度の 3 要因分散分析を 行ったところ, TPの主効果 $(F(1,8)=250.99, p<$ $.0001)$ ，モダリティの主効果 $(F(1,8)=51.72, p<$ $.0001)$, 刺激強度の主効果 $(F(1,8)=301.65, p<.0001)$, $\mathrm{TP} \times$ 刺激強度の交互作用 $(F(1,8)=34.18, p<.001)$ が有意であった. 高 TP 条件よりも中 TP 条件で, 聴 覚刺激よりも視覚刺激に対して，刺激強度が大きく 弁別が易しい条件よりも難しい条件で, 反応時間が 長かった。 TPによる反応時間の短縮 (TP 効果) は, 弁別が易しい条件よりも難しい条件で大きかった。

反応時間にみられる $\mathrm{TP}$ 効果が, 制限時間 (高 $\mathrm{TP}$ 条件 : $400 \mathrm{~ms}$, 中 $\mathrm{TP}$ 条件 : $550 \mathrm{~ms}$ ) を設定し, それ 以上時間がかかった試行を分析から除外したために 生じたものであるかどうかを検討するため, 制限時 間を超過した試行も合わせて同様の 3 要因分散分析 を行ったところ，制限時間超の試行を含まない分析 とほぼ同様の結果が得られた。すなわち，TPの主 効果 $(F(1,8)=59.12, p<.0001)$, モダリティの主効 果 $(F(1,8)=42.92, p<.001)$, 刺激強度の主効果 $(F$ $(1,8)=470.62, p<.0001), \quad$ TP $\times$ モダリティの交互作 用 $(F(1,8)=8.32, p<.05), \mathrm{TP} \times$ 刺激強度の交互作 用 $(F(1,8)=9.63, p<.05)$ が有意であつた。制限時 間内の反応時間の分析では得られなかった TP $\times モ$ ダリティの交互作用に関して下位検定を行つた結果, TP効果は視覚条件よりも聴覚条件で大きかった.

選択反応課題における各条件の正答率 (制限時間

Table 1. Mean reaction times, accuracies, P300 latencies, P300 amplitudes, P-CR latencies, LRP latencies and proportion of trials over time limits for each stimulus in each task with standard deviations in parentheses

\begin{tabular}{|c|c|c|c|c|c|c|c|c|c|c|c|c|}
\hline & \multicolumn{4}{|c|}{ Choice reaction under severe TP } & \multicolumn{4}{|c|}{ Choice reaction under moderate TP } & \multicolumn{4}{|c|}{ Simple reaction } \\
\hline & \multicolumn{2}{|c|}{ auditory } & \multicolumn{2}{|c|}{ visual } & \multicolumn{2}{|c|}{ auditory } & \multicolumn{2}{|c|}{ visual } & \multicolumn{2}{|c|}{ auditory } & \multicolumn{2}{|c|}{ visual } \\
\hline & easy & difficult & easy & difficult & easy & difficult & easy & difficult & easy & difficult & easy & difficult \\
\hline $\mathrm{RT}(\mathrm{ms})$ & $\begin{array}{l}285.3 \\
(13.8)\end{array}$ & $\begin{array}{r}319.7 \\
(6.8)\end{array}$ & $\begin{array}{l}329.8 \\
(11.4)\end{array}$ & $\begin{array}{r}355.7 \\
(9.5)\end{array}$ & $\begin{array}{l}357.8 \\
(29.0)\end{array}$ & $\begin{array}{l}414.1 \\
(15.7)\end{array}$ & $\begin{array}{l}396.1 \\
(16.6)\end{array}$ & $\begin{array}{l}442.9 \\
(20.2)\end{array}$ & $\begin{array}{l}221.9 \\
(25.0)\end{array}$ & $\begin{array}{l}280.8 \\
(18.4)\end{array}$ & $\begin{array}{l}284.5 \\
(12.8)\end{array}$ & $\begin{array}{l}327.2 \\
(11.4)\end{array}$ \\
\hline Accuracy $(\%)$ & $\begin{array}{l}77.2 \\
(11.3)\end{array}$ & $\begin{array}{l}76.4 \\
(10.7)\end{array}$ & $\begin{array}{l}72.2 \\
(7.8)\end{array}$ & & $\begin{array}{l}89.3 \\
(4.6)\end{array}$ & $\begin{array}{l}87.4 \\
(6.2)\end{array}$ & $\begin{array}{l}85.1 \\
(6.4)\end{array}$ & $\begin{array}{l}81.3 \\
(7.5)\end{array}$ & & & & \\
\hline P300 latenc & $\begin{array}{l}357.1 \\
(63.8)\end{array}$ & $\begin{array}{l}408.0 \\
(55.8)\end{array}$ & $\begin{array}{l}401.7 \\
(29.6)\end{array}$ & $\begin{array}{l}441.4 \\
(30.1)\end{array}$ & $\begin{array}{l}358.7 \\
(65.0)\end{array}$ & $\begin{array}{l}482.6 \\
(71.8)\end{array}$ & $\begin{array}{l}424.1 \\
(22.7)\end{array}$ & $\begin{array}{l}505.9 \\
(47.6)\end{array}$ & $\begin{array}{l}333.0 \\
(35.0)\end{array}$ & $\begin{array}{l}371.9 \\
(47.0)\end{array}$ & $\begin{array}{l}364.0 \\
(30.3)\end{array}$ & $\begin{array}{l}414.3 \\
(31.9)\end{array}$ \\
\hline P300 amplitude $(\mu \mathrm{V})$ & $\begin{array}{l}9.0 \\
(2.9)\end{array}$ & $\begin{array}{l}8.2 \\
(2.3)\end{array}$ & $\begin{array}{l}13.4 \\
(3.4)\end{array}$ & $\begin{array}{l}14.7 \\
(4.0)\end{array}$ & $\begin{array}{l}8.5 \\
(3.3)\end{array}$ & $\begin{array}{l}8.0 \\
(2.8)\end{array}$ & $\begin{array}{l}12.9 \\
(2.9)\end{array}$ & $\begin{array}{l}13.0 \\
(2.5)\end{array}$ & $\begin{array}{l}5.9 \\
(4.3)\end{array}$ & $\begin{array}{l}5.2 \\
(2.7)\end{array}$ & $\begin{array}{l}10.9 \\
(5.1)\end{array}$ & $\begin{array}{l}11.4 \\
(5.4)\end{array}$ \\
\hline P-CR latency (ms) & $\begin{array}{l}418.8 \\
(51.0)\end{array}$ & $\begin{array}{l}465.3 \\
(68.0)\end{array}$ & $\begin{array}{l}466.3 \\
(69.7)\end{array}$ & $\begin{array}{l}486.9 \\
(85.2)\end{array}$ & $\begin{array}{l}431.4 \\
(63.7)\end{array}$ & $\begin{array}{l}509.4 \\
(40.4)\end{array}$ & $\begin{array}{l}500.7 \\
(42.2)\end{array}$ & $\begin{array}{l}551.1 \\
(59.5)\end{array}$ & & & & \\
\hline LRP latency (ms) & $\begin{array}{l}-57.6 \\
(17.5)\end{array}$ & $\begin{array}{l}-67.0 \\
(10.3)\end{array}$ & $\begin{array}{l}-56.4 \\
(15.2)\end{array}$ & $\begin{array}{l}-59.6 \\
(23.9)\end{array}$ & $\begin{array}{l}-77.3 \\
(16.7)\end{array}$ & $\begin{array}{l}-84.4 \\
(17.6)\end{array}$ & $\begin{array}{l}-69.8 \\
(16.5)\end{array}$ & $\begin{array}{l}-72.8 \\
(18.2)\end{array}$ & & & & \\
\hline $\begin{array}{l}\text { Propototion of trials } \\
\text { over time limits }(\%)\end{array}$ & $\begin{array}{l}12.1 \\
(9.8)\end{array}$ & $\begin{array}{c}30.3 \\
(15.7)\end{array}$ & $\begin{array}{l}21.2 \\
(13.1)\end{array}$ & $\begin{array}{l}48.3 \\
(13.4)\end{array}$ & $\begin{array}{l}6.1 \\
(5.3)\end{array}$ & $\begin{array}{l}15.1 \\
(9.0)\end{array}$ & $\begin{array}{l}3.8 \\
(3.1) \\
\end{array}$ & $\begin{array}{c}19.3 \\
(10.1)\end{array}$ & $\begin{array}{l}2.4 \\
(1.3)\end{array}$ & $\begin{array}{l}10.3 \\
(6.3)\end{array}$ & $\begin{array}{l}7.1 \\
(2.9)\end{array}$ & $\begin{array}{l}30.2 \\
(8.8)\end{array}$ \\
\hline
\end{tabular}


内の反応数に対する正答の割合) を Table 1 に示す, $\mathrm{TP} \times モ$ モ゙リティ $\times$ 刺激強度の 3 要因分散分析を行 ったところ, TPの主効果 $(F(1,8)=43.55, p<.0001)$, モダリティの主効果 $(F(1,8)=10.63, p<.05)$, 刺激 強度の主効果 $(F(1,8)=23.06, p<.001)$ が有意であ つた. 中 TP 条件よりも高 TP 条件で, 聴覚条件より も視覚条件で, 刺激強度が大きく弁別が易しい条件 よりも難しい条件で，正答率が低かった。なお，単 純反応課題の正答率（制限時間内の反応）について は，聴覚・易刺激に対する正答率が非常に高く，条 件間で $S D$ のきさが大きく異なっていたので, 統 計的検定は行わなかった。モダリティと刺激強度の 効果の現れ方は, 選択反応課題と同様であった.

ERP Figure 1 に, 異なる課題で得られた 3 波形 (Pz)を重ね書きして, 刺激条件別に示した. 全部位 および全条件において, 刺激後 $300-500 \mathrm{~ms}$ 付近 で最大振幅を示す陽性電位が出現した。この陽性電 位は Pzで優勢であり，出現潜時や頭皮上分布から P300であると考えられる.

P300が最も顕著に出現した Pz 波形について, 刺 激後 $300-600 \mathrm{~ms}$ 区間で最大の陽性電位を示した 点をP300 頂点とし, その潜時と振幅を条件別に測 定した (Table 1), 単純反応課題における P300 潜時
についてモダリティ×刺激強度の 2 要因分散分析を 行つたところ, モダリティの主効果 $(F(1,8)=9.18$, $p<.05)$ と刺激強度の主効果 $(F(1,8)=64.97, p<$ .0001) が有意であった。聴覚刺激よりも視覚刺激に 対する $\mathrm{P} 300$ 潜時が長く, 易刺激よりも難刺激に対 するP300潜時が長かった。P300 振幅について同様 の分析を行った結果, モダリティの主効果 $(F(1,8)$ $=35.24, p<.001)$ のみが有意で, 視覚刺激に対する $\mathrm{P} 300$ が聴覚刺激に対するP 300 より高振幅であった。

選択反応課題における $\mathrm{P} 300$ 潜時について TP $\times$ モ ダリティメ刺激強度の 3 要因分散分析を行ったとこ ろ, TPの主効果 $(F(1,8)=62.15, p<.0001)$, モダリ ティの主効果 $(F(1,8)=7.24, p<.05)$, 刺激強度の主 効果 $(F(1,8)=88.20, p<.0001), \mathrm{TP} \times$ 刺激強度の交 互作用 $(F(1,8)=34.51, p<.001)$ が有意であった. 聴覚刺激よりも視覚刺激に対して, 弁別が易しい条 件よりも難しい条件で，P300 潜時が長かった。また, 弁別が難しい条件でのみ, 高 $\mathrm{TP}$ 条件よりも中 $\mathrm{TP}$ 条 件でP300 潜時が長かつた。なお，P300潜時につい ては，制限時間を超えた試行を含めた分析は行わな かった。本実験では制限時間を超えた時点でフィー ドバック音を呈示しており, P300の出現時間帯に フィードバック音によるERPが重複して惹起され
AUDITORY

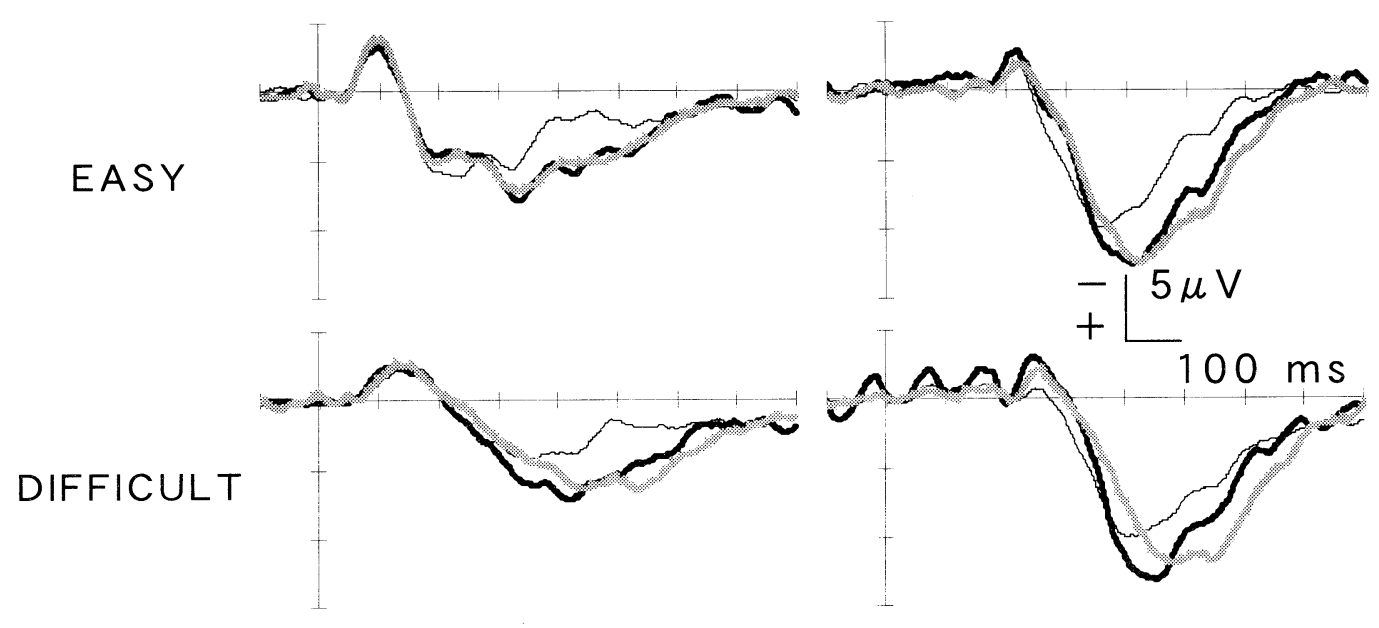

VISUAL

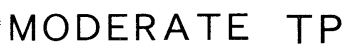

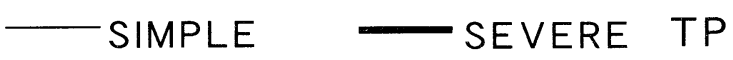

Figure 1. Grand average of ERPs at Pz plotted with overlapping waveforms for the simple reaction, severe TP, and moderate TP conditions. Waveforms for the easy stimuli and difficult stimuli are shown at the top and bottom, and waveforms for auditory stimuli and visual stimuli are shown at left and right. 


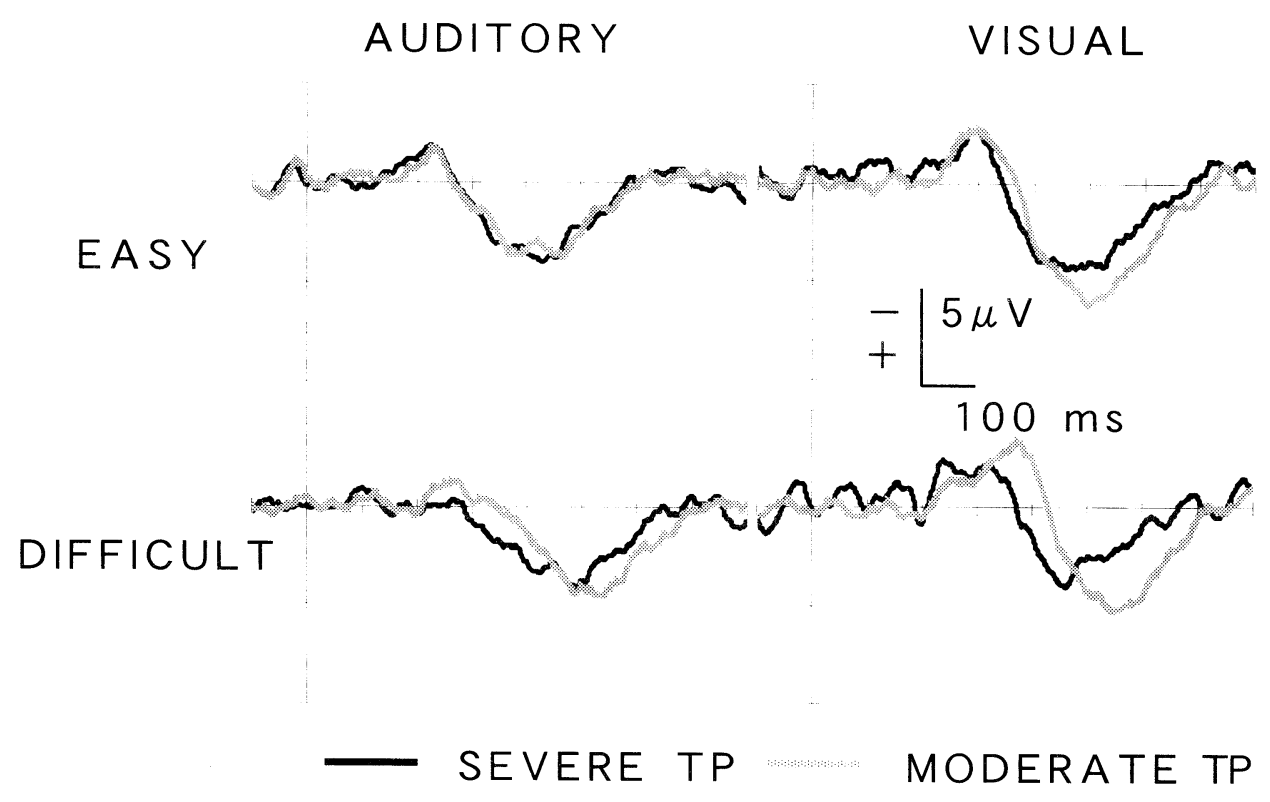

Figure 2. Grand average of the waveshapes for the difference between the ERPs of choice and simple reactions at $\mathrm{Pz}$ plotted with overlapping waveforms for the severe TP and moderate TP conditions. Waveforms for the easy stimuli and difficult stimuli are shown at the top and bottom, and waveforms for auditory stimuli and visual stimuli are shown at left and right.

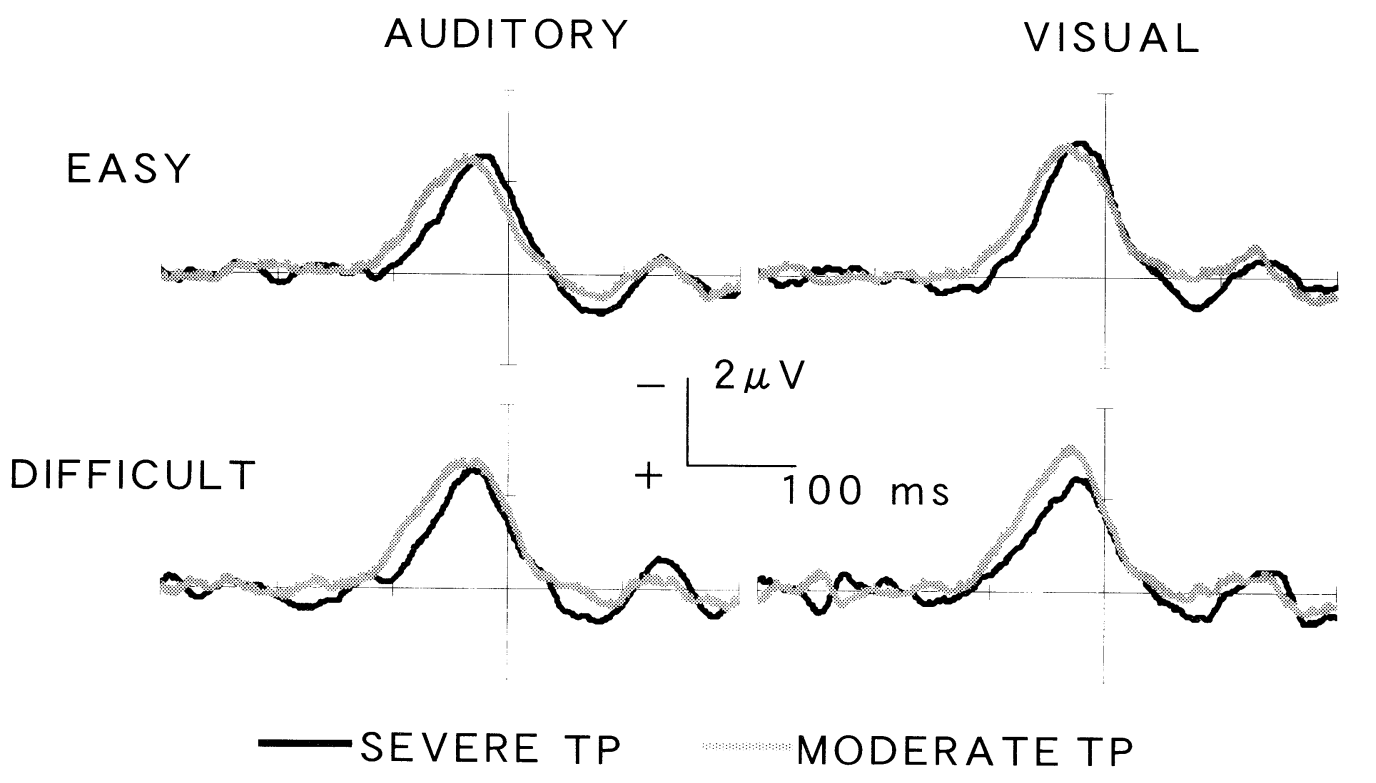

Figure 3. Grand average of the response locked LRPs plotted with overlapping waveforms for the severe TP and moderate TP conditions. Waveforms for the easy stimuli and difficult stimuli are shown at the top and bottom, and waveforms for auditory stimuli and visual stimuli are shown at left and right. 
るため, 適切な分析が行えないためである.

P300 振幅について同様の分析を行つたところ, $\operatorname{TP} の$ 主効果 $(F(1,8)=9.70, p<.05)$, モダリティの 主効果 $(F(1,8)=54.01, p<.0001)$, モダリティ×刺 激強度の交互作用 $(F(1,8)=6.98, p<.05)$ が有意で あった。 中 TP 条件よりも高 TP 条件で, 聴覚条件よ りも視覚条件で，P300 振幅が大きかった。モダリ ティによるP300 振幅の差は, 刺激強度が大きく弁 別が易しい条件よりも難しい条件で大きかった。

高 TP 選択反応課題および中 TP 選択反応課題から 単純反応課題を引いた差波形 $(\mathrm{Pz})$ を重社書きして, 刺激別に Figure 2 示す. Falkenstein et al. (1994b)に ならって，刺激後 $300-700 \mathrm{~ms}$ 区間で最大の陽性 電位を示した点をP-CR 頂点とし，その潜時を条件 別に測定した (Table 1). P-CR 潜時について TP $\times モ$ ダリティ メ刺激強度の 3 要因分散分析を行ったとこ 3, TPの主効果 $(F(1,8)=8.85, p<.05)$, モダリテ 个の主効果 $(F(1,8)=8.90, p<.05)$, 刺激強度の主効 果 $(F(1,8)=51.72, p<.0001)$ が有意であった. 高 TP 条件よりも中 $\mathrm{TP}$ 条件で, 聴覚刺激よりも視覚刺激 に対して, 并別が易しい条件よりも難しい条件で,

P-CR 潜時が長かった.

反応に同期して算出した選択反応課題時の LRP の総加算平均波形を刺激別に Figure 3 に示す。陰性 電位の最大振幅の $1 / 2$ に達した最初の時点を反応同 期 LRP 潜時とし，条件別に測定した．TP ×モダリ ティ X刺激強度の 3 要因分散分析を行ったところ, TP の主効果 $(F(1,8)=14.32, p<.01)$ と刺激強度の主 効果 $(F(1,8)=8.63, p<.05)$ が有意であった. 中 TP 条件よりも高 TP 条件で, 弁別が難しい条件よりも 易しい条件で, 反応同期 LRP 潜時とキー押し反応 との時間間隔が短かった。

\section{考 察}

本研究は, 刺激評価の難易度によって, TPが P300 に及ぼす影響が異なるかどうかを調べる目的 で行った。参加者が実際に TPを感じていたかを確 認したところ，NASA－TLXによる主観的測定に おいて, TPの項目得点のみが中 TP 条件よりも高 $\mathrm{TP}$ 条件で高くなっていた.このことから, 参加者 は中 $\mathrm{TP}$ 条件よりも高 $\mathrm{TP}$ 条件でより強く $\mathrm{TP}$ 感じ ており, TPの操作は妥当であったといえる.
単純反応課題においても選択反応課題においても, 刺激強度が大きい刺激よりも小さい刺激に対して反 応時間と P300 潜時が長くなっている. 聴覚刺激に ついては, Sugg \& Polich (1995)の, 視覚刺激につい ては, Verleger et al. (1991)の刺激強度の低下によっ て知覚的符号化が難しくなり，P300 潜時が増加す るという報告と一致している.ささらに視覚刺激のほ うが聴覚刺激よりも反応時間が長いという Falkenstein et al. (1994b) と同様のモダリティ効果が 認められている。これらのことから, 実験で用いた 刺激とその強度の操作は, 従来の研究結果と本実験 の結果を比較する上で適切であったと考えられる.

選択反応課題において, Falkenstein et al. (1994b) と同梯に, TPの増加に伴って反応時間が短くなった. この TP効果は, 制限時間を超過した試行を含めた 分析でもみられたことから, 制限時間の操作の結果 として，分析した試行に反応時間の短い試行が多く 含まれていたから生じた擬似的な効果ではなく, TPの増大により，参加者が意図的に速く反応しょ うとした結果であると考えられる。

P300潜時に関しては, 反応時間と異なり, Falkenstein et al. (1994b) と本実験の結果は一致して いない。本実験の易条件においては, 彼らの結果 (P-SR) と同様, P300 潜時は TP の影響を受けなかつ た。しかし，難条件では，TPによる P300 潜時の短 縮が観察された。 Falkenstein et al. (1994b)は, P300 を構成する 2 つ下位成分を区別し，刺激評価を反 映する P-SR はTPの影響を受けず，反応選択過程を 反映する P-CRが TPによって短縮すると主張して いる。 それに対し，本実験の知覚的符号化が難しい 条件においてはTPによってP300潜時が短縮した。 Falkenstein et al. (1994b)の主張が正しく, しかも本 実験で観察された P300 が P-CR に相当するものであ れば，その潜時の短縮が刺激評価過程への TPの影 響を反映すると結論することはできない.しかし， 本実験のP300 は, Falkenstein et al. (1994b)のいうPCR であるとは考えにくい. その理由の第 1 は, P300 潜時およびP-CR 潜時, LRP 潜時に及ぼす TP の影響の違いである. 本実験でも Falkenstein et al. (1994b) と同様の方法で同定した P-CR 潜時は, TP の増加に伴って短縮した. P-CR 潜時に関する TP $\times$ 刺激強度の交互作用は得られず，P-CR 潜時に対す 
る TP 効果は刺激強度によって変化しなかった。 LRP 潜時についても P-CR 潜時と同様であった. 一方, 反応時間および $\mathrm{P} 300$ 潜時に対する $\mathrm{TP}$ 効果は刺激強 度によって変化した。 このように，P300 潜時と P$\mathrm{CR}$ および LRP 潜時に対する TP の影響の仕方は同 じでなく, 本研究における $\mathrm{P} 300$ と Falkenstein et al. (1994b)のP-CRが同じ過程を反映しているとは考え にくい.

理由の第2 は, P300 振幅に及ぼす TP の影響である. Falkenstein et al. (1994b) では, 中 TP 条件よりも高 TP 条件で P300 振幅が大きくなっており, この効果は, P-SR と P-CR の 2 つのコンポーネントの重複が中 TPよりも高 TPで大きいために生じたと考えられて いる. P-CR と同等のコンポーネントである P4 につ いて検討した Christensen, Ivkovich, \& Drake(2001)で は，P4 は正確性を強調した教示下で，刺激の示す サイドと反応する手のサイドが異なる条件下，すな わち反応時間が遅い試行でのみ $\mathrm{P} 4$ が観察されており, TP の増大によるP-SR と P-CR の重複を示唆する結 果であるといえる。本実験でも, 中 $\mathrm{TP}$ 条件よりも 高 TP 条件で P300 振幅が大きいという結果は再現さ れた。もしもこれが P-SR と P-CRの重複によっても たらされたものであれば，P300 振幅上の TP効果は, 刺激評価が難しい条件で大きいはずである。なぜな らば，反応時間の分析で，TPによる反応時間の短 縮は, 評価が易しい条件よりも難しい条件で大きか つた（TP × 刺激強度の交互作用）からである。 Table 1 を見ると, 視覚刺激に対するP 300 振幅では, 易条件（13.4-12.9=0.5 $\mu \mathrm{V} ）$ に比べて難条件で（14.7$13.0=1.7 \mu \mathrm{V}$ ) TP効果が大きいが, 聴覚条件（易条 件 $: 1.5 \mu \mathrm{V}$, 難条件 $: 0.2 \mu \mathrm{V})$ では, その逆の結 果となっている. また, 統計的にも $\mathrm{P} 300$ 振幅に関 して TP $\times$ 刺激強度の有意な交互作用は得られてい ない.したがって，TPによるP 300 潜時の変化を, P-CRのみの潜時変化で説明するのは適切でないと 考えられる。

本実験の P300 変化をP-CR の変化であると考えに くい理由の第 3 は, TPがRTに及ぼす効果と P300 潜時に及ぼす効果の大きさの比である. Verleger (1997) は, 独立変数の操作によるRTの変化量に対 する P300 潜時の変化量の比（P300/RT 比）を指標 として， RT を変化させる変数に対する P 300 潜時の
感度を比較した。その結果, P300 潜時が刺激評価 過程を反映すると仮定（例えば，Kutas et al., 1977) した場合は，刺激評価過程への影響が想定される独 立変数 (刺激の劣化など) に対する P300/RT 比は, フランカー課題など反応過程への影響が強い課題で 得られる P300/RT 比よりも大きくなるはずであると 考えた。しかし，実際の研究報告に基づいて計算さ れた P300/RT 比は必ずしもそのようにならないこと から，P300 潜時が刺激評価過程を反映するという 仮定の妥当性を否定している. Verleger (1997)は, P300 潜時の変化をもたらす要因として, 刺激同定 過程と刺激同定後の過程を挙げている. そして, 前 者が変化した場合には P300/RT 比は大きい（67\% 以上）が，前者が変化せずに後者のみが変化した場 合には，P300/RT 比は中程度（33-67\%）以下になり， 反応時間が長くなるほどその比は小さくなるという モデルを提案している． Table 1 から TP効果に関す る P300/RT 比を計算すると，視覚・易条件では $33.8 \%$ ([424.1-401.7]/[396.1-329.8])，視覚・難条件では $74.0 \%$ （[505.9-441.4]/[442.9-355.7]）となる。 つまり， 反応時間が長い条件で大きな P300/RT 比が得られた ことになり，Verleger (1997)のモデルによって説明 できない。したがって，本実験の TPによるP P 00 潜 時の変化が刺激同定後の過程を反映すると考える根 拠は薄いといえる.

これらを総合的に考慮すると, 本実験で観察され た TPによる P 300 潜時の短縮は, 刺激評価過程の短 縮を反映すると考えられる。つまり, 従来は, TP によって刺激評価過程は影響されないと考えられて きたが，本実験のように知覚的符号化が困難で刺激 評価が難しい状況では，TPによって P300 潜時が短 縮し，TPの影響が刺激評価過程にも及ぶという新 しい知見が得られたといえる. Falkenstein et al. (1994b) では，知覚的符号化が容易な条件設定であ つたため,このような $\mathrm{TP}$ 効果が現れなかったと考 えられる。課題遂行に最も関連した処理過程に対す る課題要求が増すと, TPの影響が顕著に現れる可 能性が示唆される.

TPの増大による刺激評価過程の短縮の原因とし ては, 刺激の処理速度そのものの増加と, 刺激評価 が十分に行われる前に途中で反応が行われた可能性 との 2 つが考えられる. Table 1 を見ると，TPの増 
加に伴い, 速度一正確性のトレード・オフが生じて いる. すなわち, 反応時間が短くなると同時に, 正 答率も低下した。このトレード・オフは, 刺激強度 に関しては認められず，TP効果に固有のものであ ると考えられる，選択反応課題を行う際の情報処理 過程については, 刺激評価過程と反応準備過程は直 列的ではなく, 並列的であるとされる(松岡, 1997). 本実験では, 刺激の処理速度を推測できないため, 処理速度の増加の有無に関して結論づけることはで きないが，もう1つの可能性である刺激評価途中で の反応は生じていたと考えられる. 高 TP下では十 分な時間がないために, 刺激評価が十分に行われな いまま反応選択が行われた結果, 正答率が低下した と考えることができる.

なお, Falkenstein et al. (1994b)のようにP300をPSR およびP-CR の下位コンポーネントに分解するこ とについては, 以下のような問題があると考えられ る.まず，参加者別の波形についても，総加算平均 波形についても, 二峰性のP 300 が直接観察できな い場合が多く, P-SR と P-CR を完全に区別して同定 することが困難である点が挙げられる. 次に, 選択 反応課題の EPP 波形から単純反応課題の ERP 波形 を引き算し, P-CR を推定する方法に関して, 選択 反応と単純反応では課題の質が明らかに異なり, そ れらを引き算して得られた波形が何を反映するの かは不明である。さらに，P-SRやP-CRが反映す る心理過程についても疑問がある. Falkenstein et al. (1994b) は P-SR は刺激評価 (同定) を反映し, P$\mathrm{CR}$ は認知的な反応選択 (特定の刺激に対して, 特 定の反応を割り当てる) を反映していると主張して いる。 また， RTよりも P-CR 潜時が長いことから， P-CR は反応選択自体ではなく, 反応選択の終了あ るいは選択反応後の正確性のチエック(の終了) と 関連しているかもしれないとも述べている (Falkenstein, Hohnsbein, \& Hoormann, 1994a). それに 対し, P300/P-CR は反応選択ではなく, 刺激の分類 を反映している(Dien. Spencer, \& Donchin, 2004) と いう主張もあり，P300を構成する成分やそれぞれ が反映する心理過程については議論も多く,さらに 検討が必要である。

反応同期 LRP 潜時の結果から, 反応準備開始か ら反応実行までにかかる時間は, 中 $\mathrm{TP}$ 条件よりも
高 TP 条件で短くなっていたことが推測でき, 本実 験でもVan der Lubbe et al. (2001) と同様, TP の増加 に伴って反応準備過程が短縮していたことが示唆さ れた。 また, 反応準備開始から反応実行までにかか る時間は，刺激強度が大きく弁別が易しい条件より も難しい条件で長くなっていたことから，知覚的符 号化の困難性による遅延の影響が反応準備過程にも 及んでいると考えられる。, 一方, Miller, Ulrich, \& Rinkenauer(1999) は, 刺激強度は知覚過程後の反応 準備過程を反映する反応同期 LRPには影響しない と報告しており, 本実験の結果とは異なる。 LRPを 指標として, 速度一正確性のトレード・オフが生じ る過程を探索した Rinkenauer, Osman, Ulrich, MüllerGethmann, \& Mattes(2004)によれば, トレード・オ フは知覚符号化段階すなわち, 刺激評価過程で生じ ているだけなく, 反応準備過程でも生じており, 参 加者はスピードストレス (本研究での TP) に適応 するために, 推測によって反応する, 情報を蓄積し 反応を実行するための決定基準をコントロールする, 選択した反応の再チェックをスキップもしくは縮小 するなど，いくつかの方略を用いていると考えられ ている. 本実験と Rinkenauer et al. (2004)の参加者が 主観的に感じるTPが異なっていたとすれば, 課題 遂行のために用いられる方略も異なっていた可能性 が高い. 本実験のように選択反応が困難な事態下で は, 参加者は複数の方略を用いて TPに適応しよう としたため, 刺激評価過程においても反応準備過程 においても TPの影響がみられたと推測される.

本実験は, 知覚的符号化の困難さにより刺激評価 が難しい事態下では，TPが刺激評価過程に影響を 及ぼし、刺激評価にかかる時間が短縮することを示 すことができた．TPが情報処理過程に及ぼす影響は, 課題の難易度などの状況によって異なることが示さ れたと言える. ストレッサーとしての TPが認知的 行動を支える過程に及ぼす影響について, 系統的に 検討していく必要があると考えられる.さらに, 本 研究でみられた処理の困難性と TP の影響の関連性が, 刺激評価過程以外の処理過程についてもあてはまる のかどうかを検討することは, TPの影響のメカニ ズムを知る上で重要であると考えられる。 


\section{引用文献}

Christensen, C. A., Ivkovich, D., \& Drake, K. J. 2001 Late positive ERP peaks observed in stimulus-response compatibility tasks tested under speed-accuracy instructions. Psychophysiology, 38, 404-416.

Coles, M. G. H. 1989 Modern mind-brain reading: Psychophysiology, physiology, and cognition. Psychophysiology, 26, 251-269.

Dien, J., Spencer, K. M., \& Donchin, E. 2004 Parsing the late positive complex: Mental chronometry and the ERP components that inhabit the neighborhood of the P300. Psychophysiology, 41, 665-678.

Edland, A., \& Svenson, O. 1993 Judgment and decision making under time pressure: Studies and findings. In O. Svenson \& A. J. Maule (Eds.), Time pressure and stress in human judgment and decision making. New York, NY, US: Plenum Press. pp. 27-40.

Falkenstein, M., Hohnsbein, J., \& Hoormann, J. 1994a Effects of choice complexity on different subcomponents of the late positive complex of the event-related potential. Electroencephalography and Clinical Neurophysiology, 92, 148-160.

Falkenstein, M., Hohnsbein, J., \& Hoormann, J. 1994b Time pressure effects on late components of the eventrelated potential (ERP). Journal of Psychophysiology, 8, 22-30.

芳賀 繁・水上直樹 1996 日本語版 NASA - TLXに よるワークロード測定：各種室内実験課題に対す るワークロード得点の感度 人間工学, 32, 71-79.

Kutas, M., McCarthy, G., \& Donchin, E. 1977 Augmenting mental chronometry: The P300 as a measure of stimulus evaluation time. Science, 197, 792-795.

松岡洋夫 1997 刺激弁別と事象関連電位 丹羽真一・ 鶴 紀子 (編) 事象関連電位 新興医学出版社 pp. 51-64.

Maule, A. J., \& Edland, A. C. 1997 The effects of time pressure on human judgement and decision making. In R. Ranyard, W. R. Crozier, \& O. Svenson (Eds.), Decision making: cognitive models and explanation. London: Routledge \& Kegan Paul, pp. 189-204.
Miller, J., Ulrich, R., \& Rinkenauer, G. 1999 Effects of Stimulus intensity on the lateralized readiness potential. Journal of Experimental Psychology: Human Perception and Performance, 25, 1454-1471.

Orasanu, J., \& Connolly, T. 1993 The reinvention of decision making. In G. A. Kein, J. Orasanu, R. Calderwood, \& C. E. Zsambok (Eds.), Decision making in action: Models and methods. Norwood, NJ: Ablex, pp. 3-20.

Osman, A., \& Moore, C. M. 1993 The locus of dual-task interference: Psychologycal refractory effects on movement-related brain potentials. Journal of Experimental Psychology: Human Perception and Performance, 19, 1292-1312.

Rinkenauer, G., Osman, A., Ulrich, R., MüllerGethmann, H., \& Mattes, S. 2004 On the locus of speed-accuracy trade-off in reaction time: Inferences from the lateralized readiness potential. Journal of Experimental Psychology: General, 133, 261-282.

Sharma, D., \& McKenna, F. P. 2001 The role of time pressure on emotional Stroop task. British Journal of Psychology, 92, 471-481.

Sugg, M. J., \& Polich, J. 1995 P300 from auditory stimuli: Intensity and frequency effects. Biological Psychology, 41, 255-269.

Van der Lubbe, R. H. J., Jaśkowski, P., Wauschkuhn, B., \& Verleger, R. 2001 Influence of time pressure in a simple response task, a choice-by-location task, and the Simon task. Journal of Psychophysiology, 15, 241255.

Verleger, R. 1997 On the utility of P3 latency as an index of mental chronometry. Psychophysiology, 34, 131156.

Verleger, R., Neukäter, W., Kömpf, D., \& Vieregge, P. 1991 On the reasons for the delay of P3 latency in healthy elderly subjects. Electroencephalography and Clinical Neurophysiology, 79, 488-502.

Wickens, C. D., \& Hollands, J. G. 1999 Stress and Human Error. In C. D. Wickens \& J. G. Hollands (Eds.), Engineering psychology and human performance. 3rd ed. NJ: Prentice Hall. pp. 480-512. 